DOI: https://doi.org/10.31933/dijms.v2i1

Received: 31 August 2020, Revised: 15 September 2020, Publish: 5 November 2020

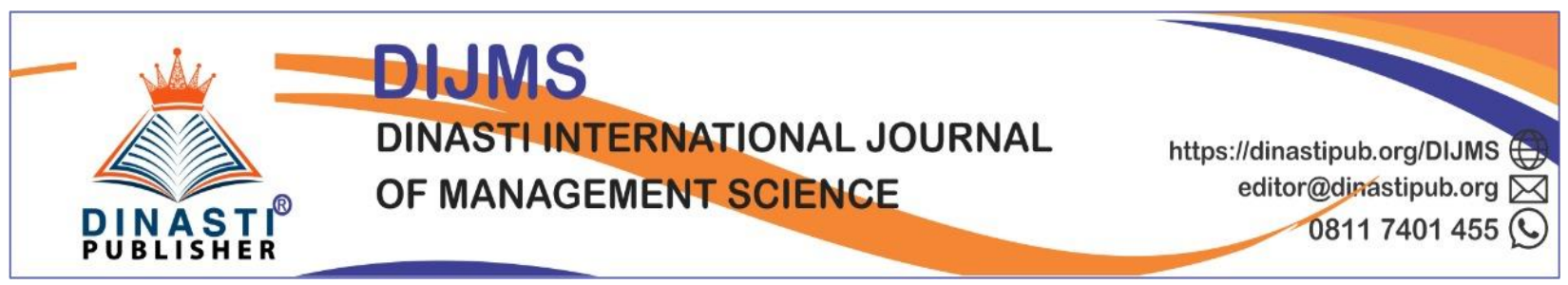

\title{
INCREASE MUZAKI LOYALTY TO THE ZAKAT, INFAQ, AND SHADAQAH MUHAMMADIYAH INSTITUTIONS IN INDONESIA
}

\section{Nasrullah Mahdar}

Economic and Business, Persada Indonesia University Y.A.I., Indonesia, correspondent.author@gmail.com

\section{Corresponding Author: First Author}

\begin{abstract}
This research aims to prove and analyze the increase in muzaki loyalty through muzaki trust as an intervening variable. The object of this research was the zakat, infaq, and shadaqah Muhammadiyah institutions (LAZISMU) with the analysis unit of Muzaki in DKI Jakarta. The research method used is descriptive and explanatory survey with a minimum sample of 200 respondents, with the data analysis method used was the Structural Equation Model (SEM). The results showed that the quality of service directly had a positive and significant effect on the trust and loyalty of muzaki; muzaki trust has a positive and significant effect on muzaki loyalty; service quality indirectly through muzaki trust has a positive and significant effect on muzaki loyalty; and service quality and muzaki trust simultaneously have a positive and significant effect on muzaki loyalty with a contribution (R2) of $65 \%$. Other findings from this study indicate that muzaki trust is a partial intervening variable on the effect of service quality on muzaki loyalty.
\end{abstract}

Keywords: Service Quality, Trust, Loyalty

\section{INTRODUCTION}

The amil zakat, infaq, and shadaqah institutions are institutions that function as intermediary institutions in conveying the mandate of muzaki to mustahik. The growth of amil zakat, infaq, and shadaqah institutions was very fast due to the attention of many parties, including the public, private institutions, government, and international institutions. An increase in the number of zakat, infaq, and shadaqah institutions that are registered or not registered with the government, this can lead to a very tight level of competition between institutions, so that it requires hard work for institutional managers to defend themselves in order to be able to compete with competitors. This competition is mainly in an effort to attract muzaki and maintain the loyalty of the existing muzaki in maintaining the existence of the institution itself.

The amil zakat, infaq, and shadaqah Muhammadiyah institutions (LAZISMU) are amil zakat institutions on a national scale, with institutional networks spread across all Provinces and Regencies in Indonesia. LAZISMU aims to be able to build collective awareness of 
Muhammadiyah members in carrying out their worship in the form of paying zakat, which is then projected zakat funds for the benefit of underprivileged Muslims. Based on data from Lazismu (2019), the potential (target) and the realization of zakat collection from all provinces in Indonesia show that the target has been not achieved. Even in the five-year period (20152019), it shows that the unattainable rate continues to increase with an average of $10 \%$ of nonachievement every year with the highest non-achievement occurring in 2019 which reached 19\%. (Oke, Kamolshotiros, Popoola, Ajagbe, \& Olujobi, 2016) through the results of their research states that the factors that influence consumer decisions are perceived values such as brand awareness, brand association, brand loyalty and perceived quality. (Oke et al., 2016) also stated that there is a positive relationship between decision making and consumer loyalty behavior, namely re-buying and word-of-mouth behavior. Meanwhile (Nischay Kumar Upamannyu \& Bhakar, 2014) states that there is a significant relationship between customer trust and repurchase intention, but when perceived CSR is used as a moderator between customer trust and customer loyalty, the relationship becomes stronger. Still according to (Nischay Kumar Upamannyu \& Bhakar, 2014), there is a strong positive relationship between customer trust and repurchase intention, but when perceived CSR is used as a moderator, the relationship between customer trust and repurchase intention becomes stronger. Other results show a strong and positive relationship between customer loyalty and repurchase intention, but when perceived CSR is used as a moderator the relationship becomes stronger.

Based on the descriptions of the two studies above, the high level of target unattainment at the Muhammadiyah amil zakat, infaq, and shadaqah institutions (LAZISMU) is due to the low loyalty of muzaki to entrust or pay zakat to these institutions. This is indicated in the muzaki retention data (2019) which shows the muzaki retention associated with LAZISMU for less than one year only reaches an average of $55.2 \%$, one year to two years only reaches an average of $33 \%$, and an average muzaki with a relationship of more than two years amounted to $11.8 \%$. Another indication that shows low muzaki loyalty is based on data on the frequency of deposits by muzaki (2019), which shows Muzaki who makes deposits more than three times a year only reaches an average of $10 \%$, and muzaki who makes deposits more than two or three times. in a year only $15.33 \%$, and muzaki who deposit only once a year is only $74.67 \%$.

Many studies on customer loyalty, apart from studies from (Nischay Kumar Upamannyu \& Bhakar, 2014) state that there is a significant relationship between customer trust and repurchase intention, but when perceived CSR is used as a moderator between customer trust and customer loyalty, the relationship becomes more strong. Other studies such as from (Nguyen, Leclerc, \& LeBlanc, 2013) state that customer trust is a mediating variable that increases the influence of corporate identity, company image and company reputation on customer loyalty. (Setiawan \& Sayuti, 2017) state some of the results of their studies, such as the influence of service quality variables, trust and company image on customer satisfaction, the influence between service quality and customer satisfaction, the influence between trust and customer satisfaction, the influence of service quality, trust and customer satisfaction on customer loyalty, the influence between service quality and customer loyalty, there is no influence of trust on customer loyalty, and the influence of customer satisfaction and customer loyalty. (Utami, 2015) through the results of his study stated that the level of trust affects customer loyalty. Meanwhile (Hayati, 2011) through his study using two models, which concluded that the best model is theoretical model 2, where model 2 with customer trust is described as an antecedent to influence customer loyalty compared to theoretical model 1 with 
customer satisfaction as an antecedent, this model shows a significant relationship between trust with customer satisfaction and loyalty.

The descriptions of the studies above indicate that the low muzaki loyalty to LAZISMU is suspected by the low trust of muzaki. This is indicated by the fact that the zakat collection data from Muhammadiyah Muslims is much smaller when compared to the number of Muhammadiyah Muslim muzaki. Another indication that shows the low trust of muzaki is based on observational data (2019) which shows that zakat distribution for Muhammaiyah residents tends to channel zakat, infaq and sadakoh institutions under Muhammadiyah organizations/ foundations with a presentation of 38.8\%. Meanwhile, 27.5\% of Muhammadiyah residents channel an institution which they are members of. Thus, the awareness of Muhammadiyah members about the existence and function of Islamic philanthropic organizations is still strong, even though they do not specifically always refer to your habits when talking about the institutions or foundations where they channel their funds. Approximately $41.2 \%$ of Muhammadiyah residents channeled zakat infaq sadakoh through two institutions, only about $22.3 \%$ through only one institution. In addition, the muzaki of Muhammadiyah members who distribute their donations directly to mustahik are still quite large, namely around $30.8 \%$. (Chu, Lee, \& Chao, 2012) stated that companies must focus on service quality to increase customer satisfaction and trust and to gain customer loyalty.

Another study states that service quality and customer trust in Islamic banks together have a significant effect on customer satisfaction. Service quality and customer trust have direct and indirect effects on customer loyalty mediated by customer satisfaction in Islamic banks. Religious commitment has no direct and indirect effect on customer satisfaction and customer loyalty (Hidayat, Akhmad, \& Machmud, 2015). (Sundaram, Ramkumar, \& Shankar, 2017) stated that the responsiveness and trust factors were highlighted as significant predictors for customer satisfaction and loyalty except for Customization. (Jiao, Moudon, \& Drewnowski, 2011) through the results of their study stated that a positive impact is seen between service quality and trust, service quality and purchase intention, and service quality and customer loyalty, as well as the mediating role of customer satisfaction has been seen in customer trust and intention buy.

The study described above shows that the low trust and loyalty of muzaki at the amil zakat, infaq, and shadaqah Muhammadiyah Institute (LAZISMU) tends to be due to the low quality of services provided by the institution. This is indicated based on several statements from muzaki, which generally state that the institution in Muzaki's eyes has never received direct reports from your common people or rarely, and this is a note for your common people regarding publication, transparency, and accountability, management and communication must be presented properly to the muzaki, and also includes making a better impression on your lazis. This needs to be done by your lazis to further increase socialization through print and electronic media and to have an office that is more accessible to Muzaki.

Based on the background description and problem identification above, the main problems of this research can be formulated as follows:

1. Is there a direct effect of service quality on the trust and loyalty of muzaki in the amil zakat, infaq, and shadaqah Muhammadiyah institutions?

2. Is there any influence of muzaki trust on muzaki loyalty to the amil zakat, infaq, and shadaqah Muhammadiyah institutions? 
3. Is there an effect of service quality on muzaki loyalty through muzaki trust in amil zakat, infaq, and shadaqah Muhammadiyah institutions?

4. Is there a simultaneous influence of service quality and muzaki trust on the loyalty of muzaki of the amil zakat, infaq, and shadaqah Muhammadiyah institutions?

\section{LITERATURE REVIEW}

\section{Service Quality}

Services for analysis purposes can be divided into three different perspectives, namely as a process, as a solution to customer problems, and as a result that is beneficial to customers (Polyakova \& Mirza, 2015). Service as a process is a process with the results of the production and consumption processes partially concurrent. This statement is in line with the statement that services are dynamic activities and processes, while 'goods' are static things (Gummesson, 2007). Service as a solution to customer problems is a customer-focused service perspective, where service is provided as a solution to customer problems (Polyakova \& Mirza, 2015). From this perspective, service is conceptualized as an intangible activity that usually takes place during interactions between customers and service personnel to provide solutions to customers. The service perspective as a result that is beneficial to customers is the main function of a business firm. This service is more to the application of specific competencies, knowledge, and skills through activities, processes, and actions for the benefit of other entities or the entity itself (Polyakova \& Mirza, 2015). Service quality is one of the main components in various businesses. Service quality in a service business is primarily the extent to which the services provided meet customer expectations and beliefs. Service quality can be said to be successful if it can only meet customer standards and expectations (Ghobadian, Speller \& Jones in (Jiao et al., 2011). This is in line with the statement that companies must provide quality services to ensure customer satisfaction and trust (Chu et al. ., 2012) Furthermore (Chu et al., 2012) stated that to ensure customer satisfaction, trust and loyalty, businesses must focus on service quality, meanwhile (Bergeron, 2001) stated that the key to business continuity and success is building and maintaining strong customer relationships Other statements reveal that system quality and service quality are the most important and determining factors for customer satisfaction and loyalty (Rodgers, Negash, \& Suk, 2005). Development of service quality measurement in this study refers to the SERVQUAL measurement scale Parasuraman et. . (1988) in (Polyakova \& Mirza, 2015) which includes five basic dimensions, namely reliability, da yes responsiveness, empathy, assurance and physical evidence. The SERVQUAL model is intended to understand general elements of service quality that are common to various services and can be applied in different industries (Polyakova \& Mirza, 2015).

Services for analysis purposes can be divided into three different perspectives, namely as a process, as a solution to customer problems, and as a result that is beneficial to customers (Polyakova \& Mirza, 2015). Service as a process is a process with the results of the production and consumption processes partially concurrent. This statement is in line with the statement that services are dynamic activities and processes, while 'goods' are static things (Gummesson, 2007). Service as a solution to customer problems is a customer-focused service perspective, where service is provided as a solution to customer problems (Polyakova \& Mirza, 2015). From this perspective, service is conceptualized as an intangible activity that usually takes place during interactions between customers and service personnel to provide solutions to customers. The service perspective as a result that is beneficial to customers is the main function of a business firm. This service is more to the application of specific competencies, knowledge, and skills through activities, processes, and actions for the benefit of other entities or the entity itself 
(Polyakova \& Mirza, 2015). Service quality is one of the main components in various businesses. Service quality in a service business is primarily the extent to which the services provided meet customer expectations and beliefs. Service quality can be said to be successful if it can only meet customer standards and expectations (Ghobadian, Speller \& Jones dalam (Jiao et al., 2011). This is in line with the statement that companies must provide quality services to ensure customer satisfaction and trust (Chu et al., 2012). Furthermore (Chu et al., 2012) stated that to ensure customer satisfaction, trust and loyalty, businesses must focus on service quality, meanwhile (Bergeron, 2001) stated that the key to business continuity and success is building and maintaining strong customer relationships Other statements reveal that system quality and service quality are the most important and Development of service quality measurement in this study refers to the SERVQUAL measurement scale Parasuraman et. al. (1988) in (Polyakova \& Mirza, 2015) which includes five basic dimensions, namely reliability, da yes responsiveness, empathy, assurance and physical evidence. The SERVQUAL model is intended to understand general elements of service quality that are common to various services and can be applied in different industries (Polyakova \& Mirza, 2015).

\section{Trust}

Trust comes from a long process (Utami, 2015). If trust has been established between the customer and the company, it will be easier to build cooperative relationships. The trust that arises is shown by the credibility gained by other parties because they have the desired expertise to carry out a task. Confidence can also be obtained by doing what is best for the other person through a relationship. The level of trust can be measured from several factors, including honesty in transactions, corporate responsibility towards consumers and other factors (Utami, 2015). Meanwhile, belief is the belief that the actions of another person or group are in accordance with their beliefs. Trust is created through a gradual process and then accumulates (Hidayat et al., 2015). Consumer trust can be explained through the dimensions of ability, virtue, and integrity. Consumer confidence depends on the ability of service providers to provide services that can provide consumer experiences in consuming goods or services that are profitable or according to consumer expectations. The ability to provide a profitable service will foster consumer confidence in a product or service. This is because experiences that are stored in the memory of consumers for a product or service are able to build someone's trust if the experience is pleasant and satisfies them. Consumer confidence will be shown through their responses to the information provided by the service provider. Consumer integrity is their positive response to the product or service they receive. Trust is an assessment of a person's relationship with other people who will carry out certain transactions in accordance with expectations in an environment full of uncertainty(Ba \& Pavlou, 2002). Trust occurs when a person believes in the reliability and integrity of people whom consumers trust (Ba \& Pavlou, 2002). Shabazz, Nagary (2008) in (Utami, 2015), the trust that customers get will result in the emergence of customer loyalty to the company. So that when conditions are difficult, customers will come to the company as helpers to keep shopping for products or services at the company.

\section{Loyalty}

Customer loyalty is a commitment to maintain in depth to repurchase or re-subscribe to the selected product or service consistently in the future, even though the influence of the situation and marketing efforts have the potential to cause changes in behavior (Griffin, 2010). According to Griffin (2010), customer loyalty can be defined as customers who make repeat purchases, buy between product and service lines, provide recommendations to others, and have immunity against competitors. Various views are given about customer loyalty or loyalty. 
Kumar dan Shah (2004) state that there are two kinds of loyalty, namely behavior and attitude. Behavioral loyalty is important for companies to increase profits, whereas loyalty is important for companies in overcoming obstacles that occur to customers. There are several approaches to measuring customer loyalty or loyalty. Loyalty theory assumes that loyalty behavior is a purchasing function, a function of the frequency of purchase or purchase patterns, a function of purchase possibilities (Kuusik, 2007). Customer loyalty exists if a company observes that its customers choose certain products from the same company, rather than using alternative products from other companies (Nischay K Upamannyu, Gulati, Chack, \& Kaur, 2015). So that customers show customer loyalty when they repeatedly buy certain products or services for a longer period of time. Organizations use a loyalty program that rewards customers for repeat business. Customer loyalty is an attitude tendency as well as a behavioral tendency to prefer one brand over another. This is due to the level of satisfaction, availability of comfort, performance, familiarity and level of comfort. Customer loyalty further encourages consumers to shop repeatedly, spend more of their income, and be positive about the shopping experience, supporting in attracting consumers to well-known brands in terms of a competitive environment (Nischay Kumar Upamannyu \& Bhakar, 2014).

\section{Framework}

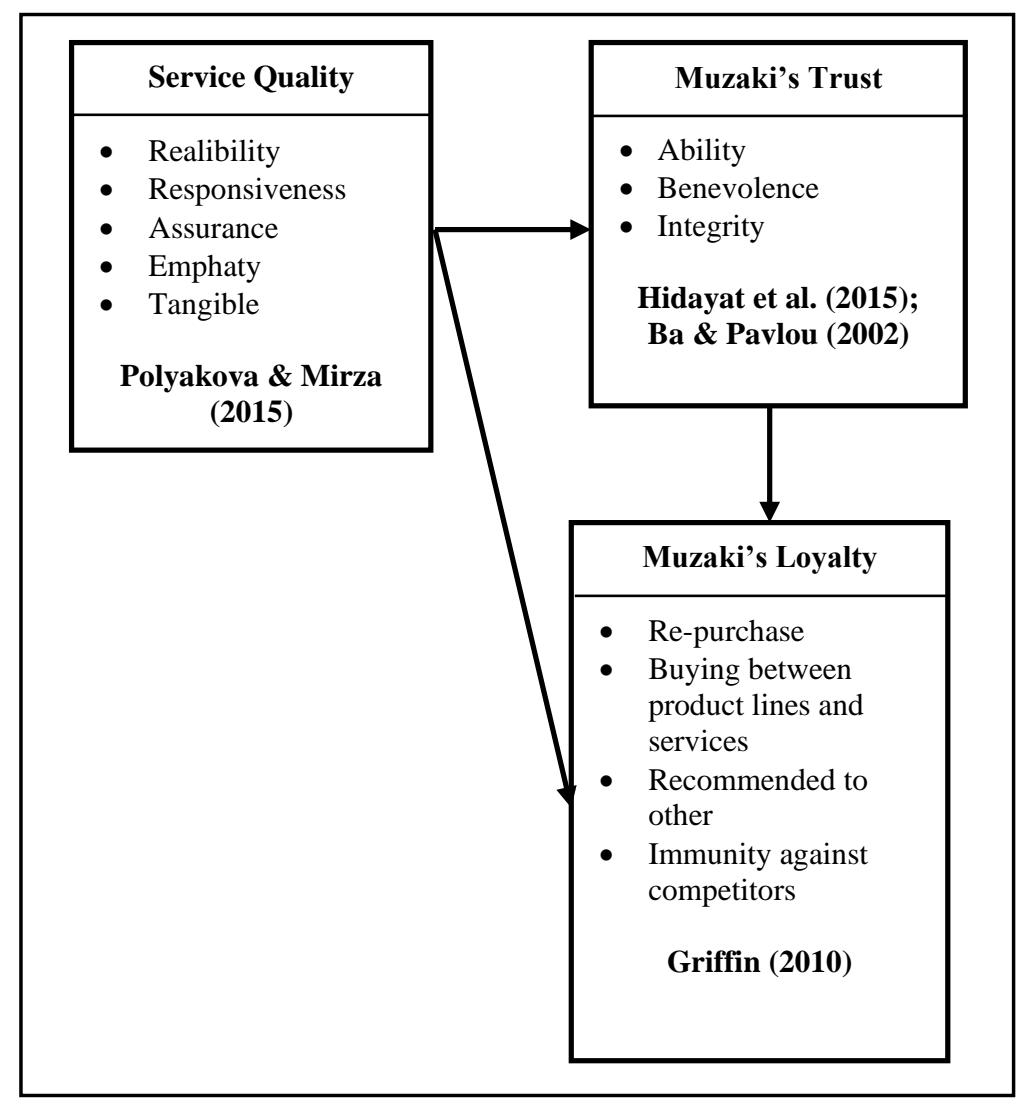

Figure 1. Framework

\section{Research Hypothesis}

Based on the description of the framework and referring to the research model design above, the research hypothesis can be described as follows:

H1: There is a direct effect of service quality on muzaki trust and muzaki loyalty. 
$\mathrm{H} 2$ : There is an effect of muzaki trust on muzaki loyalty

H3: There is an effect of service quality on muzaki loyalty through muzaki trust.

H4: There is an effect of service quality and muzaki trust simultaneously on muzaki loyalty.

\section{DATA AND ESTIMATION TECHNIQUES}

The research object which is the independent variable in this study is the quality of service, the dependent variable is the trust and loyalty of muzaki. The nature of this research is descriptive and verification. Descriptive research is research that aims to obtain a description of the characteristics of the variables. The nature of verification research basically wants to test the truth of a hypothesis which is carried out through data collection in the field. Where in this study will be tested whether the quality of service directly affects the trust and loyalty of muzaki. Does service quality affect loyalty through muzaki trust, and does service quality and trust simultaneously affect muzaki loyalty. Given the nature of this research is descriptive and verification carried out through data collection in the field, the research methods used are descriptive survey methods and explanatory survey methods. The object of research is the amil zakat, infaq, and sadakoh Muhammadiyah (LAZISMU) institutions with the unit of analysis being the muzaki.

In order to obtain data on respondents' perceptions of responses related to the research variables, dimensions are arranged which are operationalized with indicators. The operationalization of research variables is as follows:

1. Service quality is an exogenous variable measured using five dimensions, namely reliability, responsiveness, assurance, empathy, and tangible.

2. Muzaki trust is an endogenous variable that is measured using three dimensions, namely trust in ability, benevolence, and trust in integrity.

3. Muzaki's loyalty is endogenous, measured using four dimensions, namely re-purchase, buying between product lines and services, recommended to other, and immunity against competitors.

The population in this study were the Muzaki of the amil zakat, infaq, and sadakoh Muhammadiyah institutions (LAZISMU) in DKI Jakarta Province. In this study, there are three variables so that a minimum sample size of 200 muzaki is required (Hair et al, 2010: 605). The sampling method used in this research is probability sampling. Sugiyono (2013: 63), probability sampling is a sampling method that provides equal opportunities for each element (member) of the population to be selected as a sample member. While the sampling technique uses random sampling techniques.

The method of analysis and hypothesis testing in this study is in accordance with the research objectives, namely measuring the effect of the independent variable (service quality) on the dependent variable (muzaki loyalty), either directly or indirectly through the intervening variable (muzaki trust). The approach to modeling and solution techniques used is to use the Structural Equation Model method and with data processing analysis tools using the Lisrel 8.80 application program..

Table 1. Model Suitability Index 


\begin{tabular}{cccc} 
GoF indicator & Expected Index & $\begin{array}{c}\text { Estimated Result } \\
\text { Index }\end{array}$ & Test Results \\
& Absolute Fit & \\
GFI & GFI $>0,90$ & 0,86 & Marginal Fit \\
RMSEA & RMSEA $<0,08$ & 0,086 & Marginal Fit \\
& Incremental Fit & & Good Fit \\
NNFI & NNFI $>0,90$ & 0,94 & Good Fit \\
NFI & AGFI $>0,90$ & 0,94 & Marginal Fit \\
AGFI & RFI $>0,90$ & 0,78 & Good Fit \\
RFI & IFI $>0,90$ & 0,92 & Good Fit \\
IFI & CFI $>0,90$ & 0,95 & Good Fit \\
CFI & & 0,95 & \\
\hline
\end{tabular}

Source: Data Processing Results, Lisrel 8.80, 2019

Based on Table 1 above, the seven conformances obtained have a good fit measurement model suitability index, namely NNFI, NFI, RFI, IFI and CFI. Meanwhile, there are three other model suitability indices that have a marginal fit measurement model suitability index, namely GFI, RMSEA, and AGFI. The Structural Equation Model using Lisrel 8.80 is as shown in Figure 2 and Figure 3.

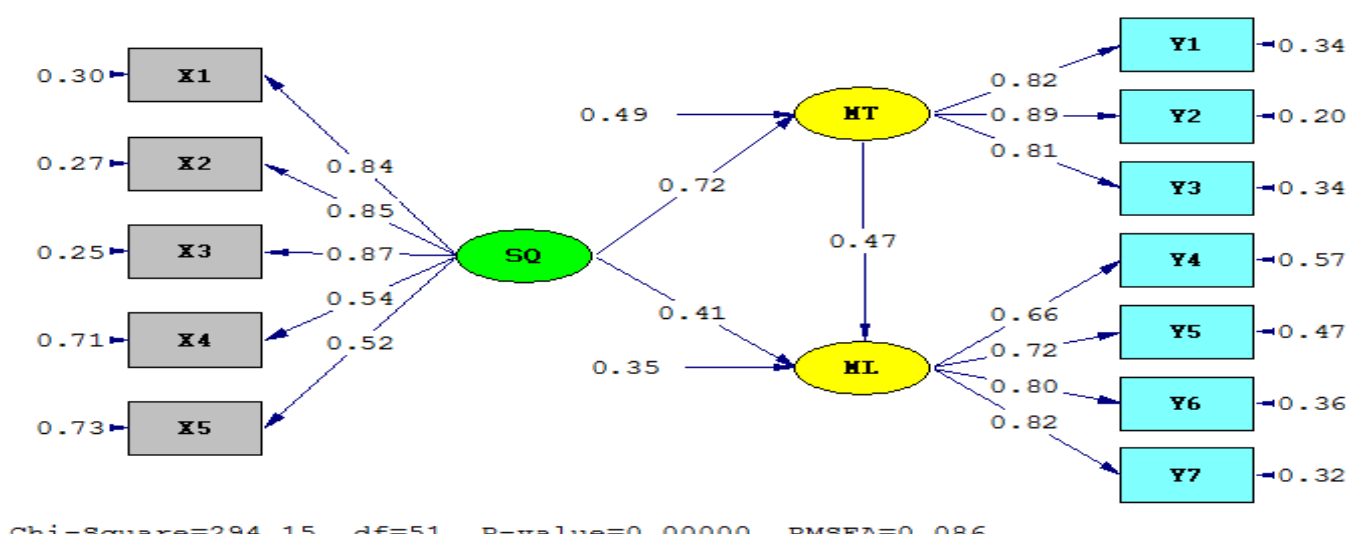

Figure 2. Structural Equation Model (Standardized)

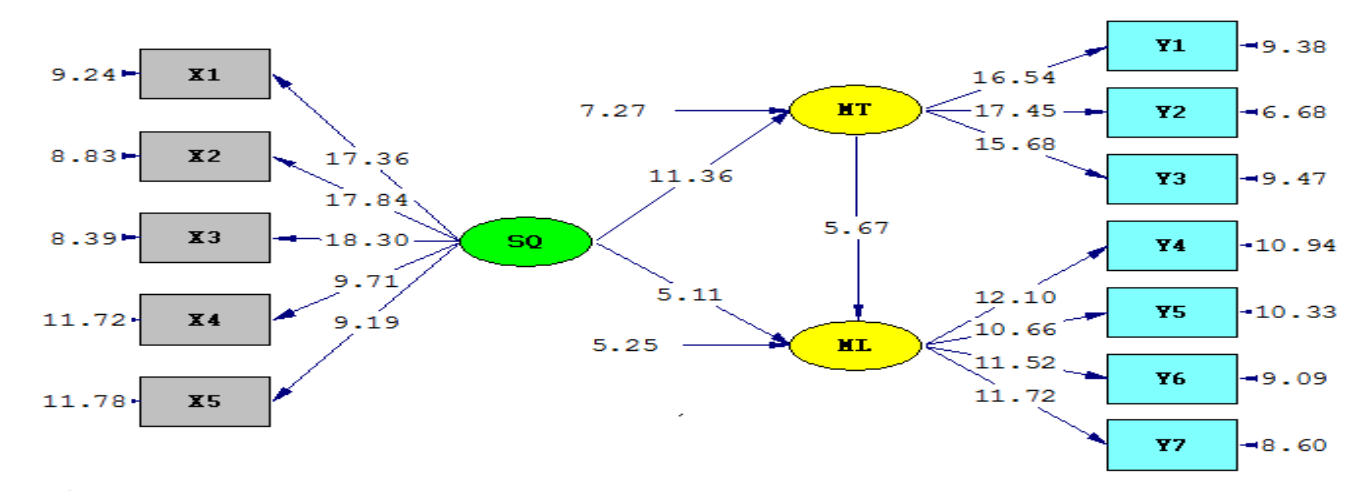

Chi-Square=294.15, df=51, P-value=0.00000, RMSEA=0.086

Figure 3. Structural Equation Model ( $t$-value)

Based on Figure 2 and Figure 3 above, the analysis of the measurement model of each variable, where for all indicators in the formation of exogenous latent variables, service quality and endogenous latent variables, muzaki trust and muzaki loyalty have good validity, this is 
indicated by all indicators have standardized Loading Factor (SLF) $\geq 0.5$ and tcount $\geq 1.96$ (at $\alpha=0.05$ ) (Hair, JF, Black, WC, Babin, BJ, \& Anderson, 2010). Likewise, both exogenous and endogenous latent variables have good model reliability, this is indicated by all variables having a construct reliability value greater than $0.70(\mathrm{CR}>0.70)$ and the extract variance value greater than $0.50(\mathrm{VE}>0.50)$.

Based on Figure 2 and Figure 3 above, the analysis of the measurement model of each variable, where for all indicators in the formation of exogenous latent variables, service quality and endogenous latent variables, muzaki trust and muzaki loyalty have good validity, this is indicated by all indicators have standardized Loading Factor (SLF) $\geq 0.5$ and t_valuet $\geq 1.96$ (at $\alpha=0.05$ ) (Hair, J.F., Black, W.C., Babin, B.J., \& Anderson, 2010). Likewise, both exogenous and endogenous latent variables have good model reliability, this is indicated by all variables having a construct reliability value greater than $0.70(\mathrm{CR}>0.70)$ and the extract variance value greater than $0.50(\mathrm{VE}>0.50)$.

Table 2. Structural Equations

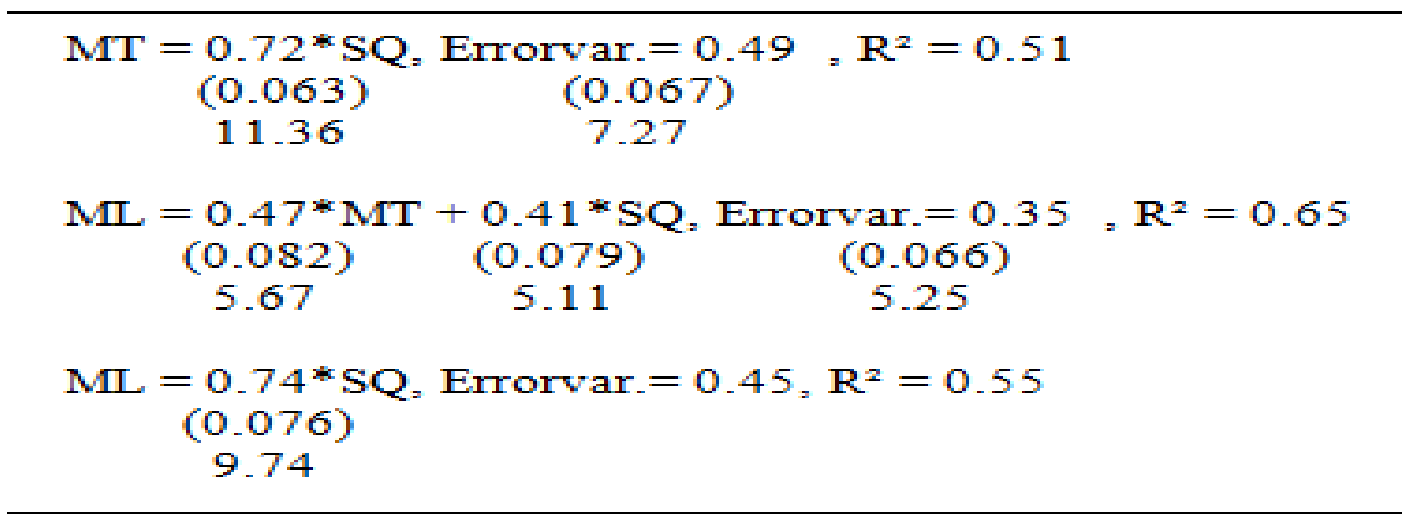

Source: Data Processing Results, Lisrel 8.80, 2019

Based on Figure 2, Figure 3, and Table 2 for structural equations, it can be argued that:

1) The value of the service quality variable path coefficient on muzaki trust is 0.72 with a t_value value of $11.36>1.96$, while the value of the service quality variable path coefficient on muzaki loyalty is 0.41 with a t_value value of $5.11>1.96$. The magnitude of the path coefficient indicates that the contribution of service quality influence on muzaki trust is $51.00 \%$, its contribution to muzaki loyalty is $16.81 \%$. So that service quality was proven to have a positive and significant effect directly on muzaki trust and muzaki loyalty or the first hypothesis is accepted.

2) The path coefficient of the muzaki trust variable to muzaki loyalty is 0.47 with a t_value value of $5.67>1.96$, so it can be said to be significant. The amount of the path coefficient indicates that the contribution of the influence of muzaki trust to muzaki loyalty is $22.00 \%$. So that muzaki trust is proven to have a positive and significant effect on muzaki loyalty or 
the second hypothesis is accepted.

3) The value of the service quality variable path coefficient on muzaki loyalty through trust is 0.34 with a value of $5.18>1.96$ (Sobel test used), so it can be said to be significant. The magnitude of the path coefficient indicates that the contribution of service quality influence on muzaki loyalty through muzaki trust is $11.56 \%$. Thus, service quality is proven to have a positive and significant effect on muzaki loyalty through muzaki trust or the third hypothesis is accepted.

4) The coefficient of determination $\left(R^{2}\right)$ of the variable service quality and muzaki trust simultaneously to muzaki loyalty is 0.65 with a value of $182.93>3.84$, so it can be said to be significant. The magnitude of the coefficient of determination $\left(R^{2}\right)$ indicates that the contribution of the influence of service quality and muzaki trust simultaneously to loyalty is $65 \%$, while $35 \%$ is the amount of influence outside the variables studied. The most dominant variable influencing muzaki loyalty is the muzaki trust variable. Thus, service quality and muzaki trust are simultaneously proven to have a positive and significant effect on muzaki loyalty or the fourth hypothesis is accepted.

The results showed that the service quality variable directly affected the muzaki loyalty variable with a contribution of $16.81 \%$. The service quality variable has an indirect effect on the muzaki loyalty variable through muzaki trust with a contribution of $11.56 \%$. So that the quality of service directly or indirectly through muzaki trust has an effect on muzaki loyalty with a contribution of $51 \%$. But simultaneously service quality and muzaki trust have an effect on muzaki loyalty with a contribution of $65 \%$. This shows that muzaki trust in this study is a partial intervening variable on the influence of service quality variables on muzaki loyalty. The results of the research findings also show that to increase the loyalty of muzaki to the Zakat Infaq and Sodakoh Muhammadiyah Institute (LAZISMU) in Indonesia, especially those reflected in the high level of Muzaki not switching to offers of similar products from other institutions, it will be able to be increased if LAZISMU is able to increase Muzaki's trust, especially those reflected by the high belief of muzaki in kindness (benevolence), while muzaki trust will increase if LAZISMU is able to improve service quality, especially as reflected in the high dimension of confidence or assurance for LAZISMU service officers.

\section{CONCLUDING REMARKS AND RECOMMENDATIONS}

1. Quality of service directly has a positive and significant effect on muzaki trust and muzaki loyalty, but the quality of service has a greater direct influence on muzaki trust. This shows that an increase in the quality of service will result in an increase in the trust of muzaki and loyalty of muzaki to the Zakat Infaq and Sodakoh Muhammadiyah Institution (LAZISMU). As for the most dominant in measuring service quality is the factor of belief or assurance in the knowledge possessed by service officers related to the problem of zakat infaq and shodakoh (ZIS). While the most dominant dimension in measuring muzaki trust is reflected by the trust factor in goodness, especially in the level of attention to muzaki, and the most dominant factor in measuring muzaki loyalty is reflected by the high level of Muzaki not turning to offers of similar products from other institutions..

2. Muzaki trust has a positive and significant effect on muzaki loyalty, this shows that increased muzaki trust will result in increased muzaki loyalty to the Zakat Infaq and Sodakoh Muhammadiyah Institute (LAZISMU). The most dominant factor in muzaki belief is reflected by the factor of trust in goodness, especially in the level of attention to muzaki, while the most dominant factor in measuring muzaki loyalty is reflected by the high level of Muzaki not turning to offers of similar products from other institutions. 
3. Service quality has a positive and significant effect on muzaki loyalty through muzaki trust, this shows that an increase in service quality will result in increased muzaki trust which has implications for increasing muzaki loyalty at the Zakat Infaq and Sodakoh Muhammadiyah Institute (LAZISMU).

4. Quality and trust of muzaki simultaneously have a positive and significant effect on muzaki loyalty, this shows that an increase in service quality and muzaki trust simultaneously will result in increased muzaki loyalty to the Infaq Zakat Institute and Sodakoh Muhammadiyah (LAZISMU) with a contribution of $65 \%$, partially muzaki trust is the most dominant in increasing muzaki loyalty. Another finding in this study concluded that muzaki trust is a partial intervening variable on the effect of service quality on muzaki loyalty.

The research findings show that if the quality of service with the guarantee of the muzaki owned can be improved, it will be able to have a positive and significant effect on increasing muzaki trust, especially in the factor of trust in the goodness given by the Institute of Zakat Infaq and Sodakoh Muhammadiyah (LAZISMU). The recommendation of these findings is to further optimize muzaki's trust in the institution by improving the quality of service by paying more attention to increasing the assurance factor of service, such as an increase in providing a sense of security in service to muzaki, service officers have knowledge related to zakat, infaq, and sodakoh who can convince muzaki, and service officers always have a polite, friendly, and patient character in serving muzaki. Other findings of the study also show that if the quality of service with a high level of assurance and muzaki trust with high muzaki trust in goodness can be synergized, it will be able to have a positive and significant effect on increasing muzaki loyalty, especially with high Muzaki not switching to offers of zakat, infaq and shodakoh. from another institution. Recommendations from the findings that can be adapted by the Institute for Zakat Infaq and Sodakoh Muhammadiyah (LAZISMU) are to optimize muzaki loyalty by increasing muzaki trust by increasing the muzaki trust factor for kindness, so that institutions must be able to increase muzaki trust in the goodness of institutional services such as improvements in attention to muzaki and increase in providing service benefits to muzaki.

\section{REFERENCES}

Ba, S., \& Pavlou, P. A. (2002). Evidence of the effect of trust building technology in electronic markets: Price premiums and buyer behavior. MIS Quarterly: Management Information Systems, 26(3), 243-268. https://doi.org/10.2307/4132332

Chu, P. Y., Lee, G. Y., \& Chao, Y. (2012). Service quality, customer satisfaction, customer trust, and loyalty in an e-banking context. Social Behavior and Personality, 40(8), 12711284. https://doi.org/10.2224/sbp.2012.40.8.1271

Gummesson, E. (2007). Exit $<\mathrm{I}>$ services $</$ I $>$ marketing - enter $<$ I $>$ service $</$ I $>$ marketing. Journal of Customer Behaviour, 6(2), 113-141. https://doi.org/10.1362/147539207x223357

Hair, J.F., Black, W.C., Babin, B.J., \& Anderson, R. E. (2010). Multivariate Data Analysis. Seventh Edition. Prentice Hall. Exploratory Data Analysis in Business and Economics. https://doi.org/10.1007/978-3-319-01517-0_3

Hayati, N. (2011). The effect of customer satisfaction , customer trust on custromer loyalty of the card users of PT. Indosat tbk. The Ird International Conference on INformation System for Business Competitiveness(ICISBC), (Yazid 2006), 91-100.

Hidayat, R., Akhmad, S., \& Machmud, M. (2015). Effects of Service Quality, Customer Trust and Customer Religious Commitment on Customers Satisfaction and Loyalty of Islamic Banks in East Java. Al-Iqtishad: Journal of Islamic Economics, 7(2), 151-164. 
https://doi.org/10.15408/ijies.v7i2.1681

Jiao, J., Moudon, A. V., \& Drewnowski, A. (2011). Grocery Shopping. Transportation Research Record: Journal of the Transportation Research Board, 2230(1), 85-95. https://doi.org/10.3141/2230-10

Nguyen, N., Leclerc, A., \& LeBlanc, G. (2013). The Mediating Role of Customer Trust on Customer Loyalty. Journal of Service Science and Management, 6(1), 96-109. https://doi.org/10.4236/jssm.2013.61010

Oke, A. O., Kamolshotiros, P., Popoola, O. Y., Ajagbe, M. A., \& Olujobi, O. J. (2016). Consumer behavior towards decision making and loyalty to particular brands. International Review of Management and Marketing, 6(4), 43-52.

Polyakova, O., \& Mirza, M. (2015). Perceived service quality models: Are they still relevant? The Marketing Review, 15(1), 59-82. https://doi.org/10.1362/146934715x14267608178721

Rodgers, W., Negash, S., \& Suk, K. (2005). The moderating effect of on-line experience on the antecedents and consequences of on-line satisfaction. Psychology and Marketing, 22(4), 313-331. https://doi.org/10.1002/mar.20061

Setiawan, H., \& Sayuti, A. J. (2017). Effects of Service Quality, Customer Trust and Corporate Image on Customer Satisfaction and Loyalty: An Assessment of Travel Agencies Customer in South Sumatra Indonesia. IOSR Journal of Business and Management, 19(5), 31-40. https://doi.org/10.9790/487x-1905033140

Sundaram, V., Ramkumar, D., \& Shankar, P. (2017). Impact of E-Service Quality on Customer Satisfaction and Loyalty Empirical Study in India Online Business. Kinerja, 21(1), 48. https://doi.org/10.24002/kinerja.v21i1.1034

Upamannyu, N. K., \& Bhakar, S. S. (2014). Effect of Customer Satisfaction on Brand Image \& Loyalty Intention : A Study of Cosmetic Product. International Journal of Research in Business and Technology, 4(1). https://doi.org/10.17722/ijrbt.v4i1.179

Upamannyu, N. K., Gulati, C., Chack, A., \& Kaur, G. (2015). The effect of customer trust on customer loyalty and repurchase intention: The moderating influence of perceived CSR. International Journal of Research in IT, Management and Engineering, 5(4), 1-31.

Utami, S. (2015). the Influence of Customers' Trust on Customer Loyalty. International Journal of Economics, Commerce and Management United Kingdom, III(7), 638-653. Retrieved from http://ijecm.co.uk/ 